Eur J Clin Chem Clin Biochem

1995; 33:59-63

(c) 1995 Walter de Gruyter \& Co. Berlin - New York

\title{
Adaptation of the Troponin T ELISA Test to a Microplate Immunoassay Reader
}

\author{
By I. Penttilä̈ ${ }^{1,2}, K$. Hirvonen ${ }^{3}$, A. Julkunen ${ }^{2}, K$. Penttilä̈ ${ }^{2}$ and T. Rantanen ${ }^{1}$ \\ 1 Department of Clinical Chemistry, Kuopio University Hospital, Kuopio, Finland \\ 2 Department of Clinical Chemistry, Kuopio University, Kuopio, Finland \\ 3 Oriola Oy Prolab, Espoo, Finland
}

(Received July 11/October 5, 1994)

Summary: Troponin $\mathrm{T}$ concentration in serum is usually measured by the automated method developed by Boehringer Mannheim for the ES-series of analysers. These instruments need at least $140 \mu \mathrm{l}$ of serum and $700 \mu \mathrm{l}$ of reagents for a single analysis, which takes $90 \mathrm{~min}$. We describe an alternative procedure, using streptavidin-coated microtitre plates, troponin $\mathrm{T}$ reagents of Boehringer Mannheim and an ELISA-reader to measure the concentration of troponin T. The present assay needs only $30 \mu \mathrm{l}$ of sample and $200 \mu \mathrm{l}$ of reagents, and it takes $75 \mathrm{~min}$; the detection limit is $0.10 \mu \mathrm{g} / \mathrm{l}$. We also assessed the microtitre plate method for sensitivity and precision and compared the results with those measured by an ES-300 automatic analyser. Both methods have the same measurement range for troponin $\mathrm{T}$ of 0.1 to $15 \mu \mathrm{g} / \mathrm{l}$. For daily routine use of the microtitre plate method we recommend duplicate determinations.

\section{Introduction}

Troponin $\mathrm{T}$ belongs to the troponin family of muscle proteins $(1,2)$. Troponins are located in the thin filament of the myocyte. Troponin $\mathrm{T}$ has the highest relative molecular mass of 37000 , other members of the family being troponin I $\left(M_{\mathrm{r}}=24000\right)$ and troponin $\mathrm{C}\left(M_{\mathrm{r}}\right.$ $=20000$ ) (2). The function of troponin $\mathrm{T}$ is to bind the other troponins to the tropomyosin filament of the myocyte. Initially the cytosolic troponin $\mathrm{T}$, but later also the complexed troponin $T$ are released from damaged muscle cells into the circulation (3). This release depends on the early reperfusion of the damaged area, and it can be utilized to follow the progress of a myocardial infarction $(3,4)$. Troponin $T$ is found in both myocardial and in skeletal muscle. Differences in the amino acid contents and structures of myocardial and skeletal troponin $T(5)$ are sufficient to permit the preparation of

\footnotetext{
') Enzymes

Isoenzyme MB of creatine kinase (EC 2.7.3.2)

Isoenzyme 1 of lactate dehydrogenase (EC 1.1.1.27)
}

highly specific antibodies against myocardial troponin $\mathrm{T}$ $(3,5,6)$. By using two selected monoclonal antibodies, Katus and coworkers (7) developed a new and highly specific enzyme-linked immunosorbent assay (ELISA) for the measurement of serum cardiac troponin $T$, in which skeletal troponin $\mathrm{T}$ in serum shows only minimal cross reactivity. Many recent studies have shown that the new troponin $T$ method is very useful in the diagnosis of acute myocardial infarction and for following the time course of cardiac muscle perfusion in patients with unstable angina pectoris $(4,7,8,9)$.

In this article we describe a modification of the original method for measuring troponin $T$ in serum, using a standard microplate immunoassay reader and the commercial reagents of Boehringer Mannheim (Mannheim, Germany) for the ES-series of analysers. A very close agreement was obtained between the results from the ES-300 analyser and those from the microtitre plate method. The microtitre plate method for troponin $\mathrm{T}$ can therefore be used in place of the ES-300 analyser (10, $11)$. 


\section{Materials and Methods}

\section{Samples}

For the present study, surplus serum from patients in the cardiac care unit of the Kuopio University Hospital, taken for ordinary serum enzyme assays, was used and stored at $-70^{\circ} \mathrm{C}(10,11)$ until analysed for serum troponin $\mathrm{T}$ concentration. Venous blood samples for enzyme determinations were collected with minimal stasis and centrifuged within $60 \mathrm{~min}$ to obtain serum for analyses. Haemolysed samples were replaced with new samples. For measuring the variations within and between series, two serum pools were made and divided into $1.0 \mathrm{ml}$ portions and stored at $-70^{\circ} \mathrm{C}$ until analysed. To evaluate the present method, patients with acute myocardial infarction. with typical clinical signs, ECG-patterns and serum enzyme') activities (12) were monitored by the serial measurement of serum troponin $\mathrm{T}$ concentration.

\section{Methods and reagents}

We measured serum troponin $T$ with an ES-300 analyser using the reagent kit of the ELISA Troponin-T Test of Boehringer Mannheim (Cat. No. 1289055$)$ for the ES-series of analysers $(10,11)$. The reagents of the kit were used as recommended by the manufacturer. The basic method uses $140 \mu \mathrm{l}$ of serum (standard or control) and $700 \mu \mathrm{l}$ of the mixture of two antibodies, the first complexed with biotin and the second with peroxidase. After incubation of the mixture for $60 \mathrm{~min}$ at $25^{\circ} \mathrm{C}$, the tubes were washed, substrate was added (di-ammonium 2,2'-azino-bis[3-ethylbenzothiazoline-6sulphonate] and $\mathrm{H}_{2} \mathrm{O}_{2}$ ), and the tubes were incubated for $30 \mathrm{~min}$ at $25^{\circ} \mathrm{C}$ for colour formation. The colour intensity was then measured at $405 \mathrm{~nm}$ (tab. 1) and the troponin T concentration obtained from the standard curve as calculated by the instrument.

Unmodified reagents produced by Boehringer Mannheim were used for the determination of serum troponin $T$ concentration as a microtitre plate immunoassay method. Instead of the original tubes, the reaction was performed in the $250 \mu \mathrm{l}$ wells of a microtitre plate after coating the wells with streptavidin. The wells of the microtitre plate were coated for $24 \mathrm{~h}$ with streptavidin from Boehringer Mannheim (14 U/mg) at a concentration of $10 \mathrm{mg} / \mathrm{l}$ in $10 \mathrm{mmol} / \mathrm{l}$ phosphate buffer, $\mathrm{pH} 7.2$ containing $150 \mathrm{mmol} / \mathrm{l} \mathrm{NaCl}$ at $+4^{\circ} \mathrm{C}$. The binding capacity of streptavidin for biotin on the walls of the wells was at least $2 \mathrm{ng}$ of biotin per well, which was found to be sufficient. Commercial microtitre plates coated with streptavidin (Boehringer Mannheim and Labsystems Oy, Helsinki, Finland) could also be used. Coated microtitre plates were stored at $+4^{\circ} \mathrm{C}$ until used. Otherwise, the method was similar to that used with the ES-300 analyser, with minor modifications of the ratios of sample and reagent volumes (tab. 1). Sera, standards and controls were dispensed into the wells of the plate with a manual pipette (Proline 5-50, Biohit Oy, Helsinki, Finland). The tip of the pipette was changed after each operation. The mixture of antibodies to troponin $\mathrm{T}$ was then added with a multitip automated pipette (Proline Electronic 250, Biohit Oy). The plate was incubated for $60 \mathrm{~min}$ at $25^{\circ} \mathrm{C}$ in a Wellwarm 1 shaker (Denley Instruments Ltd, Billingshurst, England) then washed twice with the washing solution using a Multiwash instrument (Labsystems Oy, Helsinki, Finland). The substrates (di-ammonium 2,2'-azino-bis[3-ethylbenzothiazoline-6-sulphonate] and $\mathrm{H}_{2} \mathrm{O}_{2}$ ) were then added and the microplate was incubated on a Multiscan MCC/340 reader (Labsystems Oy) for $15 \mathrm{~min}$, after which the concentration of the colour in the wells was read at $405 \mathrm{~nm}$. The concentrations of troponin $T$ were then obtained from a standard curve made with the Multiscan reader.

The standard curve for troponin $\mathrm{T}$ was constructed by using the following kit standards: $0.0,0.9,2.4,5.2,10.7$ and $14.5 \mu \mathrm{g} / 1$. The controls purchased with the kit were low $(0.19 \pm 0.06 \mu \mathrm{g} / \mathrm{l})$ and high $(5.45 \pm 0.82 \mu \mathrm{g} / \mathrm{l})$. The fitting of the standard curve was studied by different modes of the Multiscan reader and also by using a microcomputer.

For comparison of the clinical usefulness of the microtitre plate troponin $T$ method, the activity of serum creatine kinase ${ }^{\prime}$ ), its iso- enzyme $M B$, the activity of lactate dehydrogenase and its isoenzyme 1 as well as the mass concentration of creatine kinase-MB were measured. The activity of creatine kinase in serum was measured using a commercial assay by Boehringer Mannheim according to the ECCLS recommendation (13) and Hitachi 717 Analyser (Tokyo, Japan). The activity of serum creatine kinase-MB was measured with the Boehringer Mannheim kit which incorporates an antibody for inhibition of the M-subunit; the value obtained for the creatine kinase- $B$ subunit was then doubled. The mass concentration of creatine kinase-MB in serum was measured with a commercial IMx ${ }^{\circledR}$ creatine kinase-MB assay (Abbott Laboratories, Abbott Park, Chicago, Ill., USA); the method uses a monoclonal anticreatine kinase-MB antibody bound to latex microparticles; the second antibody is a polyclonal anti-creatine kinase-MM antibody coupled with alkaline phosphatase (14). After inhibition of the Mcontaining isoenzymes with urea and quinidine at $\mathrm{pH} 10$, lactate dehydrogenase and its isoenzyme lactate dehydrogenase-1 were measured using the lactate dehydrogenase-method of Boehringer Mannheim and a Hitachi 717 analyser in accordance with the Scandinavian Recommendation (15).

\section{Statistics}

The coefficients of variation and the correlation coefficients between the different methods were calculated using the StatView 4.0 software package (Abacus Concepts Inc., Berkeley, U.S. A.). The results are expressed as the mean values with corresponding standard deviations. The curve fittings by a microcomputer were performed using SPSS/PC+ Statistical Data Analysis package (SPSS Inc., Chicago, USA).

:

\section{Results and Discussion}

Evaluation of the microtitre plate ELISA method for the determination of troponin $T$ in serum

The purpose of the present investigation was to study the possibility of adapting the commercial troponin $\mathrm{T}$ test of Boehringer Mannheim to a standard microtitre plate ELISA method using the reagents of the manufacturer as supplied for the ES-series of analysers. Each step of the method was tested, and the results of serum analyses were compared with those obtained with an ES-300 analyser. In table 1 both procedures are presented.

The linearity of the Multiscan ELISA-reader was studied by using $10 \mathrm{mmol} / \mathrm{K}$-dichromate solution. It was found that the instrument was linear at $405 \mathrm{~nm}$ up to an absorbance value of 2.400 . Using solutions of $\mathrm{K}$-dichromate with absorbance values of 0.387 or 1.561 , we pipetted $30 \mu \mathrm{l}$ of the colour red solution with a single-tip manual pipette (Proline 5-50) and $200 \mu \mathrm{l}$ of $\mathrm{H}_{2} \mathrm{O}$ with a multitip automated pipette (Proline Electronic 250) into the 250 $\mu \mathrm{l}$ wells of microtitre plates (from Labsystems). The coefficients of variation were 0.96 and $0.74 \%$, respectively.

The optimal streptavidin coating of the microtitre plate wells was checked by using the highest troponin T standard and steptavidin-coated plates from Labsystems (the 
Tab. 1 Protocols for the determinations of serum troponin $T$ with the microplate immunoassay and with an ES-300 analyser. ABTS ${ }^{\circledR}$ $=$ diammonium 2,2'-azino-bis(3-ethylbenzothiazoline-6-sulphonate).

\begin{tabular}{lll}
\hline Step in assay & Microplate & ES-300 \\
\hline $\begin{array}{l}\text { Sample/Standard } \\
\text { Anti-troponin T antibody, } \\
\text { biotinylated }\end{array}$ & $30 \mu l$ & $140 \mu \mathrm{l}$ \\
$\begin{array}{l}\text { Anti-troponin T antibody } \\
\text { peroxidase conjugated }\end{array}$ & $200 \mu \mathrm{l}$ & $700 \mu \mathrm{l}$ \\
$\Downarrow$ & &
\end{tabular}

Microtitre wells or tubes coated with streptavidin. The plates or tubes were incubated for $60 \mathrm{~min}$ at $25^{\circ} \mathrm{C}$ with continuous mixing.

Washing the samples and extra reagents one/two times with washing solution.

\section{Addition of reagents $\mathrm{ABTS}^{\circledR}$ and $\mathrm{H}_{2} \mathrm{O}_{2}$}

$\begin{array}{lcc}\text { Volume } & 200 \mu \mathrm{l} & 700 \mu \mathrm{l} \\ \text { Incubation of the mixture at } 25^{\circ} \mathrm{C} & 15 \mathrm{~min} & 30 \mathrm{~min} \\ \Downarrow & & \end{array}$

Measurement of the colour directly from the microtitre plate wells or after transferring the coloured liquid to the cuvettes (ES-300) at $405 \mathrm{~nm}$.

Calculation of the results from the standard curves made by the instruments.

binding capacity was stated to be at least $2 \mathrm{ng}$ biotin per well). By varying the sample size (from 10 to $50 \mu \mathrm{l}$ ) it was found that $30 \mu \mathrm{l}$ or less resulted in similar values to those obtained with an ES-300 analyser, but with sample volumes of $40 \mu \mathrm{l}$ and $50 \mu \mathrm{l}$ the results were too low ( -12 and $-32 \%$, respectively). We also coated the wells of a microtitre plate with different concentrations of streptavidin (Boehringer Mannheim) and found that a $250 \mu \mathrm{l}$ well should bind at least $2 \mathrm{ng}$ of biotin, based on the analysis of $30 \mu \mathrm{l}$ of the highest troponin T standard (the streptavidin tubes for the ES-series of analysers have a binding capacity of approximately $14 \mathrm{ng}$ of biotin per tube).

Using an incubation temperature of $25^{\circ} \mathrm{C}$, it was shown that the incubation times can be the same as in the original method. However, the reaction time for substratechromogen solution could be shortened from $30 \mathrm{~min}$ to $15 \mathrm{~min}$ in the microtitre plate technique (tab. 1). It was also found that the incubation and the wash steps in the microtitre plate method should be performed mechanically rather than manually, in order to obtain constant results. After checking the conditions, the standard curve of the microtitre plate method was curvilinear (fig. 1) as is the standard curve of the ES- 300 analyser. The measurement range was the same for both methods ( 0.1 to $15 \mu \mathrm{g} / \mathrm{l})$. The point-to-point calculation mode and the second degree regression mode gave the best results with the present method.

The difference between duplicate analyses were studied over the whole measuring range by using human serum samples. Figure 2 shows clearly that the percentage differences increase at lower and higher troponin $T$ concentrations. The situation was somewhat better when greater amounts of streptavidin were used for coating the microplate wells (data not shown). At concentrations below the lowest standard $(0.9 \mu \mathrm{g} / \mathrm{l})$, the relative differences were so high that duplicate analyses are recommended for routine laboratory practice. In contrast, with an ES300 analyser, single determinations seem to fulfil the

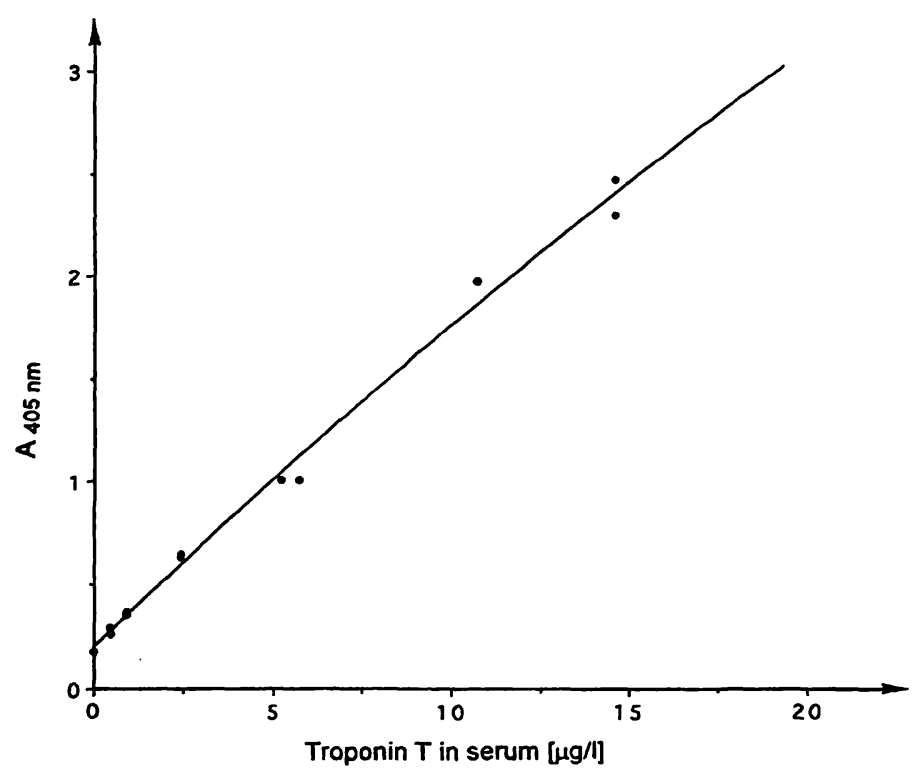

Fig. 1 A typical standard curve of the troponin $T$ method for the microplate immunoassay method.

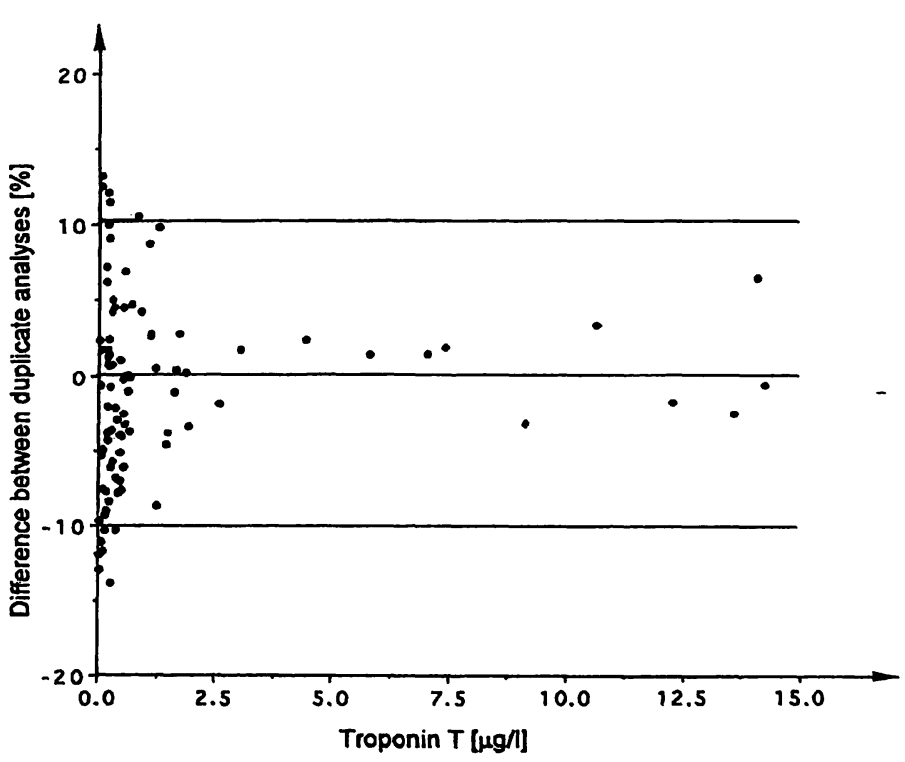

Fig. 2 Percentage differences between duplicate analyses for serum troponin $\mathrm{T}$ measured by the microplate immunoassay method. 
Tab. 2 The within and between series variation of the troponin $\mathrm{T}$ microplate method, using low and medium serum pools, and controls from the manufacturer. The assayed values for the troponin $\mathrm{T}$ control sera were: low $0.19 \pm 0.06 \mu \mathrm{g} / \mathrm{l}$ and high 5.2 $\pm 0.82 \mu \mathrm{g} / \mathrm{l}$.

Coefficient of variation

of troponin $\mathrm{T}$ method within series

\begin{tabular}{llllll}
\hline Sample level & \multicolumn{2}{l}{ Serum pool } & & \multicolumn{2}{l}{ Control serum } \\
\cline { 2 - 3 } \cline { 6 - 7 } & Low & High & & Low & High \\
\hline Mean $(\mu \mathrm{g} / \mathrm{l})$ & 0.237 & 2.28 & & 0.229 & 4.60 \\
CV $(\%)$ & 1.52 & 1.92 & & 2.44 & 2.23 \\
No. of analyses & 10 & 10 & & 10 & 10 \\
\hline
\end{tabular}

Coefficient of variation

of troponin $\mathrm{T}$ method between series

\begin{tabular}{|c|c|c|c|c|}
\hline \multirow[t]{2}{*}{ Sample level } & \multicolumn{2}{|c|}{ Serum pool } & \multicolumn{2}{|c|}{ Control serum } \\
\hline & Low & High & Low & High \\
\hline Mean $(\mu \mathrm{g} / \mathrm{l})$ & 0.242 & 2.13 & 0.234 & 4.35 \\
\hline CV (\%) & 12.9 & 10.0 & 12.7 & 7.67 \\
\hline No. of analyses & 8 & 8 & 8 & 8 \\
\hline
\end{tabular}

criteria of acceptance even in the lower concentration range (11).

Variations within and between series were studied by using frozen serum pools and control samples (tab. 2). At the troponin $\mathrm{T}$ concentrations of 0.2 and $2.2 \mu \mathrm{g} / \mathrm{l}$ in serum pools or 0.2 and $4.5 \mu \mathrm{g} / 1$ in control samples, the within series variations were between 1.52 and $2.44 \%$. The variations between series were higher and ranged from 7.67 to $12.9 \%$ (tab. 2). It is possible that small variations in the streptavidin binding capacity can increase the coefficient of variation at the lower range, or that the streptavidin binding capacity of the wells should be greater.

The highest standard concentration in the kits is 14.5 $\mu \mathrm{g} / \mathrm{l}$. In daily laboratory practice, several values are higher than this, suggesting that the sample should be diluted. The only obvious problem of standardisation is the absence of a standard concentration near the critical value of the measurement (between 0 and 0.9 $\mu \mathrm{g} / \mathrm{l})$. Such a standard would help to increase the accuracy of the measurement of low serum troponin $T$ values.

A very close agreement was found between the methods when the values from the microtitre plate technique were compared with those obtained with an ES300 analyser (fig. 3). The mean values for 42 human sera did not significantly differ for the two methods $(\mathrm{r}=0.99)$.
Detection limit, reference values and

discrimination limit of the microtitre plate assay

The detection limit for troponin $\mathrm{T}$ in serum with the present microtitre plate method wạs about $0.10 \mu \mathrm{g} / \mathrm{l}$ when defined as the mean of 14 non-specific binding values $+3 \mathrm{SD}$. In the sera of 63 healthy laboratory personnel, more than $95 \%$ of all troponin $\mathrm{T}$ values were below $0.10 \mu \mathrm{g} / \mathrm{l}$, the highest value being $0.19 \mu \mathrm{g} / \mathrm{l}$. By doubling the value of $0.10 \mu \mathrm{g} / \mathrm{l}$ it can be stated that troponin $\mathrm{T}$ values in serum exceeding $0.20 \mu \mathrm{g} / \mathrm{l}$ should be regarded as abnormal. This limit corresponds well with those presented earlier $(4,10,11,16)$.

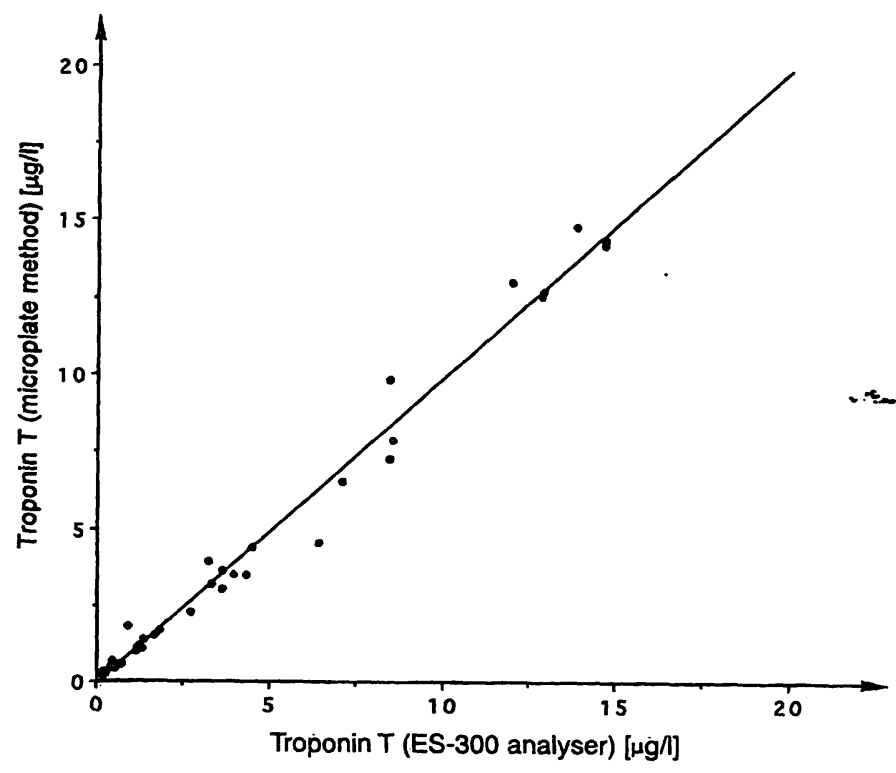

Fig. 3 The comparison of the results for serum troponin $T$ measured with the microplate immunoassay method and with an ES300 analyser. $y=-0.059+0.988 x(x=E S-300, y=$ microplate method). $\mathrm{N}=42, \mathrm{r}=0.99$.

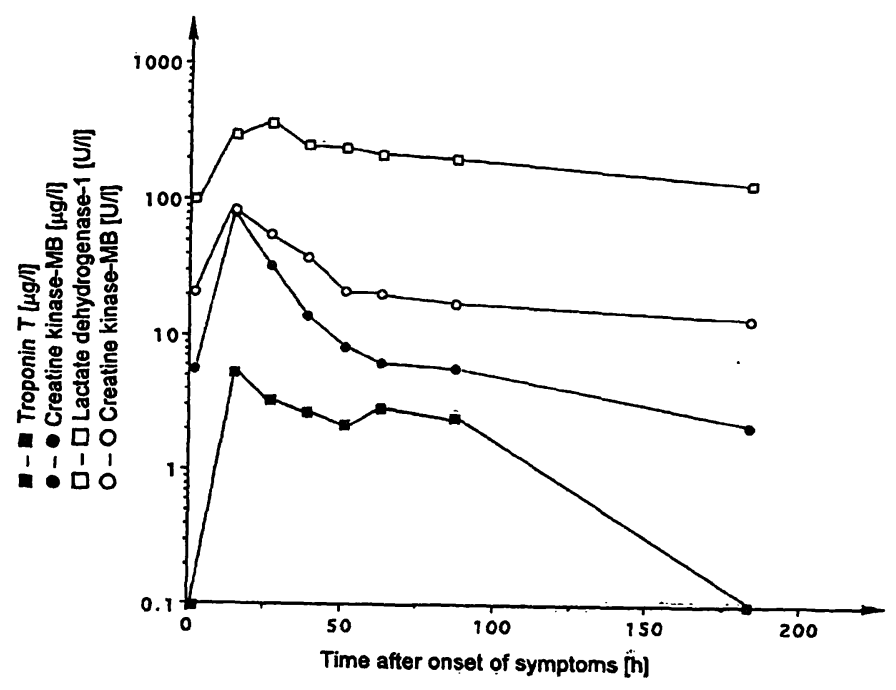

Fig. 4 A typical time-curve of serum troponin $T$ (1) compared with the catalytic activity concentrations of creatine kinase-MB (o) and lactate dehydrogenase isoenzyme $1(\square)$ and the mass concentration of creatine kinase-MB (๑) in the serum of a patient with acute myocardial infarction. 
In figure 4 , typical changes of serum troponin $T$ and enzyme values in a patient with acute myocardial infarction with early reperfusion are presented. This clinical result obtained with our modified method corresponds well to previous observations made with automated assays for troponin $T$ in serum $(3,4,7,11,16)$.

\section{Conclusion}

A comparison of the values obtained with the microtitre plate immunoassay method with those from an ES-300 analyser shows that the microtitre plate method can be

\section{References}

1. Saprans I, Takahash H, Russel MP, Watanabe S. Skeletal and cardiac troponins and their components. Biochem J 1972; 72:723-35.

2. Greaser ML, Gergeley J. Purification and properties of the components from troponin. J Biol Chem 1973; 248:2125-33.

3. Katus HA, Remppis A, Looser S, Hallermeier K, Scheffold T, Kübler W. Enzyme linked immunoassay of cardiac troponin $T$ for the detection of acute myocardial infarction in patients. $J$ Mol Cell Cardiol 1989; 21:1349-53.

4. Gerhardt W, Katus H, Ravkilde J, Hamm C, Jørgensen PJ, Peheim E, Ljungdahl L, Löfdal P. S-troponin T in suspected ischemic myocardial injury compared with mass and catalytic concentrations of s-creatinine isoenzyme MB. Clin Chem $1991 ; 37: 1405-11$.

5. Briggs MM, Schachat F. N-terminal amino acid sequences of three functionally different troponin $\mathrm{T}$ isoforms from rabbit skeletal muscle. J Mol Biol 1989; 206:245-9.

6. Scheffold T, Temppis A, Kübler W. Only one troponin T isoform is expressed in the failing human heart. Eur Heart $J$ 1991; 12(suppl):215.

7. Katus HA, Looser S, Hallermeir K, Remppis A, Scheffold T, Borgya A, Essig U, Geuss U. Development and in vitro characterization of a new immunoassay for cardiac troponin $\mathrm{T}$. Clin Chem 1992; 38:386-93.

8. Hamm CW, Ravkilde J, Gerhardt W, Jørgensen P, Peheim E, Ljungdahl L, Goldman B, Katus HA. The prognostic value of serum troponin $\mathrm{T}$ in unstable angina. $\mathrm{N}$ Engl $\mathrm{J}$ Med 1992; 327:146-50.

9. Hamm CW, Katus HA, Ravkilde J, Goldmann BU, Bleifeld W, Gerhardt W. Identification of high-risk patients with unstable angina by troponin T release. Circulation 1992; 82(Supp III):7.

10. Penttilä I, Helin $M$, Julkunen $A$, Miettinen $M$, Rantanen $T$. Evaluation of ES-300 ELISA analyzer for the measurement of troponin- $T$ in the diagnosis of acute myocardial infarction. Clin Chem 1992; 38:965-6. used for the measurement of serum troponin $T$ concentration. The day-to-day variation still has to be reduced and we are currently working on this problem. From a clinical point of view the present method fulfils the needs of daily clinical laboratory practice for the diagnosis of acute myocardial infarction, thus confirming the usefulness of the troponin $T$ assay.

\section{Acknowledgement}

The authors thank Mr. Tero Hongisto for technical assistance and Pharm. Dr. Even McDonald for revising the English language.
11. Penttilä 1, Helin $M$, Julkunen $A$, Miettinen $M$, Rantanen $T$. Evaluation of an ES-300 ELISA analyzer for the measurement of troponin- $T$ in the diagnosis of acute myocardial infarction. LabMedica International 1993; X:16-9.

12. World Health Organization. Report of the fifth working group on the establishment of ischemic heart disease registers. WHO, Copenhagen 1971.

13. European Committee for Clinical Laboratory Standards. Standards for enzyme determination: creatine kinase, aspartate aminotransferase, alanine aminotransferase, gamma-glutamyltransferase; 1988 ECCLS Document ISSN 1011-6265, No. 3-4.

14. Brandt DR, Gates RC, Eng KK, Forsythe CM, Korom CK, Notro AS, Koffler PA, Ogunro EA. Quantifying the MB isoenzyme of creatine kinase with the Abbott "IMx" immunoassay analyzer. Clin Chem 1990; 36:375-78.

15. Keiding $P$, Hørder $M$, Gerhardt W, Pitkänen E, Tenhunen R, Strømme JH, Theodorsen L, Waldenström J, Tryding $M$, Westlund L. Recommended methods for the determination of four enzymes in blood. Scand J Clin Lab Invest 1974; 33:291-306.

16. Ravkilde J, Hørder M, Gerhardt W, Ljungdahl L, Pettersson T, Tryding N, Møller BH, Hamfelt A, Graven T, Åsberg A, Helin $\mathrm{M}$, Penttilä I, Thygesen K. Diagnostic performance and prognostic value of serum troponin $\mathrm{T}$ in suspected acute myocardial infarction. Scand J Clin Lab Invest 1993; 53:677-85.

Professor Ilkka Penttilä, M.D., Ph. D. Department of Clinical Chemistry Kuopio University Hospital FIN-70210 Kuopio Finland 
-.

$\cdot 1$

- - 